\begin{tabular}{llllllll}
$\mathbf{A}$ & $\mathbf{R}$ & $\mathbf{T}$ & $\mathbf{Y}$ & $\mathbf{K}$ & $\mathbf{U}$ & $\mathbf{L}$ & $\mathbf{Y}$ \\
\hline
\end{tabular}

ROCZNIKI HUMANISTYCZNE

Tom LXVIII, zeszyt $9 \quad-2020$

DOI: http://dx.doi.org/10.18290/rh20689-1

ŁUKASZ JUREŃCZYK

\title{
UWARUNKOWANIA BUDOWY I ROZWOJU BAZY MORSKIEJ CHIŃSKIEJ REPUBLIKI LUDOWEJ W DŻIBUTI
}

\author{
CONDITIONS FOR THE CONSTRUCTION AND DEVELOPMENT \\ OF THE NAVAL BASE OF THE PEOPLE'S REPUBLIC OF CHINA IN DJIBOUTI
}

\begin{abstract}
A bstract. The subject of the article is the conditions for the construction and development of the People's Republic of China's naval base in Djibouti. It consists of an introduction, three parts and conclusion. The introduction discusses the methodological assumptions of the article. The first part presents the reasons for the location of China's first foreign naval base in Djibouti. The second part is devoted to issues concerning the base's construction and development. The third part examines the consequences of locating a Chinese base in Djibouti for the purpose of strategic rivalry between states. The research takes into account both the local, regional and global perspective. The most important conclusions and summaries, as well as prospects for the development of the base in Djibouti and further activities of the PRC in the field of maritime expansion, are presented at the end.
\end{abstract}

Key words: People's Republic of China; Djibouti; naval base; Navy; economic investments.

Budowa przez Chińską Republikę Ludową (ChRL) pierwszej zagranicznej bazy morskiej potwierdza wzrost znaczenia mórz i oceanów w polityce zagranicznej i bezpieczeństwa Państwa Środka. Postrzegana jest ona jako kolejny krok w zwiększaniu odpowiedzialności Chin za międzynarodowe bezpieczeństwo, jak również projekcji siły zbrojnej na świecie. Wśród konkurentów Pekinu pogłębia ona obawy o kierunki przyszłej jego polityki i zachowanie jej pokojowego charakteru. Kontrowersje wzbudza również wybór

Dr hab. ŁUKASZ JUREŃCZYK, prof. UKW - Uniwersytet Kazimierza Wielkiego w Bydgoszczy, Wydział Nauk o Polityce i Administracji, Katedra Polityki Bezpieczeństwa; adres do korespondencji: ul. ks. J. Poniatowskiego 12, 85-671 Bydgoszcz; e-mail: lukaszjurenczyk@, ukw.edu.pl. ORCID: https://orcid.org/0000-0003-1149-925X. 
na bazę małego państwa - Dżibuti, zlokalizowanego w strategicznym miejscu Rogu Afryki. Wzmożona aktywność ChRL w tym państwie, jak i w całym regionie Afryki Wschodniej i Bliskiego Wschodu zmusza też do postawienia pytania o kwestię dalszego przywiązania Pekinu do tradycyjnie wyznawanych zasad w polityce zagranicznej. Wielkie inicjatywy o charakterze polityczno-gospodarczym, które wymagają zabezpieczenia w wymiarze militarnym, zmuszają również do zastanowienia się nad wzrastającym wpływem Chin na środowisko międzynarodowe.

Celem artykułu jest analiza i ocena uwarunkowań budowy i rozwoju bazy morskiej Chińskiej Republiki Ludowej w Dżibuti. Głównym problemem badawczym jest pytanie, jakie są rzeczywiste cele budowy przez Chiny pierwszej zagranicznej bazy w tym rejonie. Podstawową tezą artykułu jest stwierdzenie, że baza jest elementem stopniowego zwiększania wojskowej obecności Chińskiej Armii Ludowo-Wyzwoleńczej (People's Liberation Army - PLA) na świecie. Zjawisko to jest konsekwencją globalnego rozwoju chińskich interesów gospodarczych i politycznych. Baza morska w Dżibuti przede wszystkim potrzebna jest Pekinowi do ochrony inwestycji ekonomicznych w regionie Afryki Wschodniej i Bliskiego Wschodu. Za jej pośrednictwem chce on mieć zwiększony wpływ na sytuację bezpieczeństwa i procesy polityczno-gospodarcze zachodzące $w$ tych regionach. W artykule skorzystano z metody analizy źródeł tekstowych.

\section{POWODY WYBORU DŻIBUTI POD BUDOWĘ CHIŃSKIEJ BAZY MORSKIEJ}

ChRL i Dżibuti ustanowiły stosunki dyplomatyczne 8 stycznia 1979 r. Relacje między państwami od początku były poprawne i ulegały stopniowemu rozwojowi, koncentrując się przede wszystkim się na sferze ekonomicznej. W 2014 r. wartość wymiany handlowej między Chinami i Dżibuti wyniosła 1,1 mld USD (Repetowicz). Azjatycka potęga gospodarcza jest głównym źródłem kapitału dla tego małego państwa afrykańskiego, które ma aspiracje stania się ważnym centrum finansowo-handlowym w regionie. Chińskie przedsiębiorstwa dostarczają prawie 40\% (1,4 mld USD) środków do realizacji głównych projektów inwestycyjnych. Ponadto realizują budowę trzech sztandarowych przedsięwzięć infrastrukturalnych, tj. wielozadaniowego portu Doraleh w Balbala na południowo-zachodnich przedmieściach stolicy kraju - Dżibuti, połączenia kolejowego dla pociągów wysokich pręd- 
kości z portu Doraleh do stolicy Etiopii - Addis Abeby oraz rurociągu do transportu wody z Etiopii do Dżibuti. Dwa pierwsze projekty zostały ukończone w 2017 r. We współpracy inwestycyjnej między ChRL a Dżibuti pojawiają się pewne problemy. Dżibuti w zasadzie nie ma jednak alternatywy w wyborze partnera gospodarczego, co wynika $\mathrm{z}$ niechęci finansowania jego niepewnych przedsięwzięć przez państwa zachodnie i kontrolowane przez nie międzynarodowe instytucje finansowe (Downs, Becker i deGategno 10-16). W lipcu 2018 r. prezydent Dżibuti Ismail Omar Guelleh (od 05.1999) przedstawił projekty Międzynarodowej Strefy Wolnego Handlu i Przedsięwzięcia Międzynarodowych Parków Przemysłowych, które mają zostać zrealizowane wspólnie z ChRL za 3,5 mld USD. Ekonomiści ostrzegają, że tak duże inwestycje realizowane za pieniądze pożyczone od Pekinu mogą w krótkim czasie wepchnąc Dżibuti w pułapkę zadłużenia. W takiej sytuacji znalazły się inne małe państwa, które znajdują się na drodze Morskiego Jedwabnego Szlaku (Maritime Silk Route), w tym Sri Lanka i Malediwy. Uzależnienie gospodarcze, a co za tym idzie - polityczne, pozwala z kolei Chinom na realizację własnej polityki na ich terenie, w tym budowę sieci portów na Oceanie Arabskim, tzw. „Sznura Pereł” („String of Pearls”) (Cheng).

Dżibuti zlokalizowane jest na obszarze wulkanicznym, znajdujące się tam twory geologiczne są jednak nieaktywne. W bezpośrednim sąsiedztwie Dżibuti jest Cieśnina Bab al-Mandab, która otwiera wyjście z Zatoki Adeńskiej na Morze Czerwone, prowadzące dalej do Kanału Sueskiego. Znacznie strategiczne tego punktu jest więc ogromne. ChRL ma największy udział w światowym handlu, a aż 95\% międzynarodowej wymiany gospodarczej odbywa się drogą morską. Towary przechodzące przez Cieśninę Bab al-Mandab przekraczają $12 \%$ całości wolumenu wyrobów sprzedawanych na świecie. Tą drogą Chiny dostarczają do Europy większość wyprodukowanych u siebie towarów przemysłowych i importują część bliskowschodniej ropy naftowej. Dla Chin utrzymanie wolności żeglugi w tym rejonie jest więc nieocenione z punktu widzenia zabezpieczenia inwestycji zagranicznych. Strategiczna waga tego obszaru dla chińskiego handlu międzynarodowego plasuje go zaraz po otwierającej dostęp do Morza Południowochińskiego Cieśninie Malakka (Li, Zhao, Zhang, Cao i Zhang 59-60).

$\mathrm{Z}$ prawie 1,3 tys. chińskich okrętów handlowych, które w 2008 r. przepłynęły przez Zatokę Adeńską, siedem zostało zaatakowanych przez somalijskich piratów (Dong 171), a nawet $20 \%$ znalazło się pod jakiegoś rodzaju presją z ich strony (Dend 105). W związku z tym w grudniu 2008 r. Chiny rozmieściły na tym akwenie morską zadaniową grupę konwojową (escort 
task force) w celu wsparcia rezolucji Rady Bezpieczeństwa ONZ nr 1816 z 2 czerwca 2008 r. dotyczącej zwalczania piractwa morskiego („Resolution 1816 (2008)"). Standardowo grupa składa się z dwóch fregat, okrętu zaopatrzeniowego, helikopterów i żołnierzy sił specjalnych. Czasowo była wzmacniana przez atomową łódź podwodną. Realizuje ona operacje konwojowe w Zatoce Adeńskiej i na sąsiednich wodach terytorialnych Somalii (Li, Kemburi i Hongzhou 16). Te działania stanowią pierwsze przedsięwzięcie oceaniczne okrętów wojennych daleko poza wodami przybrzeżnymi Chin od czasu misji admirała Zheng He w XV wieku. Operacja w Zatoce Adeńskiej przywołuje skojarzenia z ekspedycją z czasów dynastii Ming nie tylko ze względu na podobieństwo przebytego szlaku, ale także symbolicznego poczucia odrodzenia się potęgi Chin (Dend 105).

Rejon styku Rogu Afryki i Bliskiego Wschodu jest szczególnie ważny dla administracji Prezydenta Xi Jinpinga (od 03.2013) w kontekście realizacji sztandarowej inwestycji „Jeden Pas, Jedna Droga” („One Belt, One Road” OBOR). Ponadto szereg państw zlokalizowanych w bliskim i dalszym sąsiedztwie Dżibuti zgłosiło chęć dołączenia do tworzonego przez ChRL Azjatyckiego Banku Inwestycji Infrastrukturalnych (Asian Infrastructure Investment Bank - AIIB), w tym Arabia Saudyjska, Egipt, Iran, Izrael, Jordania, Katar, Kuwejt, Oman, Turcja i Zjednoczone Emiraty Arabskie (ZEA) (Lanteigne 201). Decyzja umiejscowienia pierwszej bazy morskiej w państwie afrykańskim wynikała również z dynamicznego wzrostu poziomu inwestycji Chin na tym kontynencie. Chińskie inwestycje bezpośrednie w Afryce tylko między 2011 a 2015 r. uległy więcej niż podwojeniu, tj. wzrosły z 16 do 35 mld USD. Poziom pożyczek udzielonych państwom afrykańskim wzrósł z kolei do 63 mld USD. W tym samym czasie, według oficjalnych statystyk, liczba chińskich obywateli pracujących na kontynencie wzrosła ze 180 do 260 tys. Nieoficjalne dane wskazują jednak, że w Afryce może mieszkać między 1 a 2 milionami Chińczyków (Becker i Downs). ChRL chce również dynamizować współpracę gospodarczą z państwami sąsiedniego Bliskiego Wschodu. Podczas wystąpienia w styczniu 2016 r. w siedzibie Ligi Państw Arabskich (League of Arab States - LPA/LAS) w Kairze prezydent Xi Jinping zapewnił o wydzieleniu poważnych środków na rozwój regionu i współpracę dwustronną (Szumski). Szczególne zainteresowanie Chin dotyczy współpracy gospodarczej z Arabią Saudyjską. Chcą one między innymi stać się głównym importerem saudyjskiej ropy naftowej, prześcigając w tym zakresie Stany Zjednoczone (Hayoun).

Dżibuti znajduje się pomiędzy dwoma regionami, w których znajduje się szereg punktów zapalnych i prowadzone są liczne konflikty zbrojne, tj. Afryką 
Środkowo-Wschodnią i Bliskim Wschodem. Wśród zdestabilizowanych militarnie państw należy przede wszystkim wymienić Jemen, Somalię, Sudan Południowy, Republikę Środkowej Afryki, Kenię, Libię, Syrię i Irak (Lanteigne). W państwach tych działają także tysiące organizacji przestępczych i terrorystycznych. Aby chronić własnych obywateli, Chiny zwiększają swoje zdolności w zakresie działań antyterrorystycznych. Ćwiczenia o takim charakterze odbyły się między innymi w Dżibuti w maju 2018 r. (Becker i Downs). Należy zaznaczyć, że samo Dżibuti jest państwem stabilnym politycznie, można więc powiedzieć, że niejako znajduje się w oku wschodnioafrykańskiego i bliskowschodniego cyklonu. Chiny dynamicznie zwiększają swoją odpowiedzialność za międzynarodowe bezpieczeństwo, co przede wszystkim dotyczy Afryki. W ramach misji pokojowych na tym kontynencie stacjonuje ponad 2,5 tys. chińskich żołnierzy, głównie w takich państwach, jak Południowy Sudan, Liberia i Mali. W 2015 r. Chiny zadeklarowały 8 z 40 tys. żołnierzy w ramach sił stojących w gotowości do realizacji misji pokojowych ONZ. Jednocześnie przekazały $100 \mathrm{mln}$ USD na wsparcie misji pokojowych Unii Afrykańskiej (African Union - UA/AU) (Repetowicz). Lokalizacja bazy w Dżibuti była dobrym wyborem, także zważywszy na fakt, że wojna w Jemenie znacząco ograniczyła możliwość korzystania przez chińskie okręty z sąsiedniego portu w Adenie. W związku z tym Pekin musi w większym stopniu polegać na bazie w Dżibuti, jak również porcie Salalah w Omanie (Lubell).

Zanim Chiny rozpoczęły budowę instalacji w Dżibuti, zlokalizowane tam były już bazy wojskowe Stanów Zjednoczonych, Francji, Japonii, Hiszpanii i Włoch. Oznacza to między innymi, że w Dżibuti znajdują się bazy dwóch państw, z którymi Chiny mają wyjątkowo skomplikowane i napięte stosunki w wymiarze polityczno-wojskowym. Konkurent Chin z Azji Wschodniej Japonia - w 2011 r. wybudowała w Dżibuti swoją pierwszą pełnoprawną zamorską bazę wojskową wyposażoną w infrastrukturę portową. Głównym celem jej budowy miało być wsparcie udziału jej okrętów w antypirackiej operacji u wybrzeży Somalii, w której uczestniczy od 2009 r. (Maslow 191). Z kolei Camp Lemmonier, od 2003 r. należący do globalnego rywala Chin Stanów Zjednoczonych, jest jedyną stałą bazą amerykańską na kontynencie afrykańskim, a stacjonuje $\mathrm{w}$ niej ponad 4 tys. żołnierzy i jedno z największych na świecie zgrupowań dronów. Ta baza służy przede wszystkim rozpoznawaniu zagrożeń i koordynacji działań na zdestabilizowanych obszarach Somalii i Jemenu oraz innych państw, głównie regionu Afryki Wschodniej (Cheng). 


\section{BUDOWA I ROZWÓJ \\ CHIŃSKIEJ BAZY MORSKIEJ W DZIBUTI}

W 2013 r. Państwowy Uniwersytet Obrony w Pekinie (National Defense University - NDU) przedstawił Chińskiej Centralnej Komisji Wojskowej (China's Central Military Commission - CMC) raport naukowy, w którym sugerował budowę bazy w Dżibuti. Stojący na czele CMC Prezydent Xi Jinping zatwierdził ten raport („Djibouti - China Naval Base”). W maju 2015 r. chiński rząd poinformował o negocjacjach dotyczących lokalizacji w Dżibuti swojej pierwszej zagranicznej bazy morskiej. Mimo sprzeciwu ze strony Stanów Zjednoczonych rokowania zostały pomyślnie sfinalizowane. W listopadzie 2015 r. Pekin oświadczył, że podpisał z Dżibuti 10-letnie porozumienie o dzierżawie terenu pod budowę bazy logistycznej i dyslokację w niej do 10 tys. żołnierzy. Umowa weszła w życie w styczniu 2016 r., a już miesiąc później rozpoczęła się budowa instalacji w portowym mieście Obock w Dżibuti (Henry 20). Do prac przy jej konstrukcji CMC wyznaczyła specjalną drużynę złożoną z 80 oficerów i żołnierzy („Djibouti - China Naval Base"). Baza o powierzchni 200 akrów została dobrze ufortyfikowana czterema warstwami ochronnych ogrodzeń. Dwa wewnętrzne żywopłoty mają od 8 do 10 metrów wysokości, a na ich drodze jest szereg posterunków strażniczych (Cheng). W bazie ma się znajdować sześć przystani dla statków o łącznej długości 1200 metrów. Według nieoficjalnych raportów jedna z nich ma być przeznaczona specjalnie dla Marynarki Wojennej Chińskiej Armii Ludowo-Wyzwoleńczej (People's Liberation Army Navy - PLAN) i być w stanie przyjąć nawet największe okręty chińskiej floty wojennej, tj. lotniskowiec Liaoning i amfibię transportową klasy Yuzhao. Wśród obiektów wybudowanych na terenie bazy ma się znajdować przynajmniej dziesięć budynków koszarowych, magazyny na paliwo, broń i wyposażenie, a także budynki i urządzenia przeznaczone do konserwacji śmigłowców oraz cywilnych i wojskowych okrętów oraz lotnisko. Pod powierzchnią bazy mają być $\mathrm{z}$ kolei wybudowane pomieszczenia o powierzchni 23 tys. $\mathrm{m}^{2}$ (Downs, Becker i deGategno 25-26).

W lipcu 2017 r. w bazie rozlokowane zostały okręty Floty Morza Południowego, operujące wcześniej na akwenie Morza Południowochińskiego. 1 sierpnia 2017 r. miała miejsce oficjalna uroczystość otwarcia bazy, a w połowie września przeprowadzono w jej rejonie ćwiczenia z użyciem amunicji bojowej (Headley). Jeszcze większe ćwiczenia zostały przeprowadzone w listopadzie 2018 r. z użyciem fregaty rakietowej, ciężkiej artylerii, sił lądowych, 
transporterów opancerzonych i helikopterów. Były to piąte ćwiczenia z ostrą amunicją przeprowadzone w Dżibuti i jak dotąd największe ćwiczenia wojskowe, jakie PLA przeprowadziła na obcej ziemi (Jeong-ho).

Pod koniec maja 2018 r. rzecznik prasowy ministerstwa obrony ChRL, pułkownik Ren Guoqiang (od 02.2016), ogłosił, że podjęto decyzję o budowie dodatkowej instalacji portowej w bazie w Dżibuti w postaci mola. Uzasadniając tę decyzję, powiedział, że jest to konieczne do jeszcze bardziej skutecznego wypełniania przez Chiny międzynarodowych zobowiązań, w tym w zakresie operacji antypirackiej, oraz zwiększenia wkładu w utrzymanie pokoju i stabilności w Afryce i na świcie. Molo wydłużyło infrastrukturę bazy o 330 metrów w głąb morza (Becker i Downs).

Władze chińskie utrzymują, że instalacja w Dżibuti ma przede wszystkim przeznaczenie cywilne. Uspokajają, że jej budowa nie ma nic wspólnego ze zwiększaniem obecności wojskowej Chin w regionie i wyścigiem zbrojeń. Unikają stosowania wojskowej terminologii dla opisania bazy i jej roli. Określają bazę mianem ,zaplecza wsparcia technicznego" lub „zaplecza logistycznego" (Headley). Faktycznie morska baza w Dżibuti koncentruje się głównie wokół zadań o charakterze logistyczno-technicznym, ponieważ chińskie okręty mogą korzystać z instalacji tego rodzaju zlokalizowanych na jej obszarze. Umożliwia im to zatankowanie i uzupełnienie zasobów we własnej, bezpiecznej bazie (Jeong-ho). Załogi statków, w tym głównie pełniących misję antypiracką, mogą z kolei regularnie odpoczywać na lądzie. Wcześniej okręty i ich załogi musiały polegać na rozmieszczonych $\mathrm{w}$ regionie okrętach logistycznych. Z racji oddalenia Zatoki Adeńskiej o 7 tys. km od terytorium Chin musiały one jednak przebyć tę drogę w ciągu 7-9 dni i za opłatą dokować w porcie w Dżibuti („Djibouti - China Naval Base”). Obecne rozwiązanie jest więc dużo bardziej efektywne i opłacalne.

Władze Stanów Zjednoczonych i wielu państw sojuszniczych nie dają wiary informacjom o bazie w Dżibuti przekazywanym przez chińskie źródła rządowe. Uważają one, że baza ma głównie przeznaczenie stricte wojskowe, a akcentowanie kwestii techniczno-logistycznych ma być przykrywką dla rzeczywistych celów budowy bazy. Według ekspertyzy Centrum Analiz Morskich (Center for Naval Analyses) z Wirginii w USA chińska baza w Dżibuti ma przede wszystkim wspierać cztery rodzaje operacji, tj. antypirackie, ewakuacyjne, pokojowe i antyterrorystyczne, a także służyć do zbierania danych wywiadowczych i ochrony strategicznych szlaków morskich (Downs, Becker i deGategno 30-31). Możliwość zbierania danych wywiadowczych w regionie ma przede wszystkim umożliwić zbudowane na 
terenie bazy lotnisko. W zachodnich mediach pojawiają się nawet informacje o nielegalnych działaniach wojskowych, które rzekomo miałyby być realizowane na terenie bazy. Na przykład mają być z niej kierowane źródła światła laserowego w stronę latających w jej sąsiedztwie amerykańskich samolotów. W wyniku tej domniemanej działalności o prowokacyjnym charakterze miało nawet dojść do zranienia dwóch amerykańskich pilotów. Pekin jednoznacznie zaprzecza tego typu zarzutom i insynuacjom (Headley).

\section{STRATEGICZNE UWARUNKOWANIA BUDOWY I ROZWOJU CHIŃSKIEJ BAZY MORSKIEJ W DŻIBUTI}

Władze ChRL argumentują, że celem budowy i rozwoju bazy morskiej w Dżibuti jest wypełnienie międzynarodowych zobowiązań Chin w zakresie bezpieczeństwa. Powołują się na uczestnictwo w regionie w misjach antypirackich, humanitarnych i pokojowych. Baza pozwala także na utrzymanie gotowości do ewakuacji własnych obywateli z rejonów zagrożonych konfliktami zbrojnymi i ich ochronę przed zagrożeniem terrorystycznym. Wprawdzie zjawisko piractwa morskiego na wodach Rogu Afryki zostało już praktycznie zwalczone w 2013 r., to ogólna niestabilność regionu powoduje, że argumentacja Pekinu może być przekonująca. Trzeba mieć jednak na uwadze, że ChRL przede wszystkim zainteresowana jest ochroną własnych interesów $\mathrm{w}$ regionie. Oficjalne stanowisko rządu stoi w zgodzie z promowaną od dekad zasadą polityki zagranicznej - nieingerencji w sprawy wewnętrzne państw. Wzmożona aktywność gospodarcza Chin w regionie i przede wszystkim umiejscowienie bazy morskiej daje jednak Chinom potencjalną możliwość wpływania na sąsiednie państwa, szczególnie te pogrążone w konfliktach, oraz na stosunki między nimi (Wang). W praktyce Pekinowi trudno będzie trzymać się tej zasady w okolicznościach tak zdestabilizowanego i pogrążonego w konfliktach regionu.

Przez dekady Stany Zjednoczone i państwa Europy Zachodniej były głównymi zewnętrznymi aktorami na Bliskim Wschodzie i w Afryce Wschodniej. Obecnie w tych regionach swoją pozycję umacniają Chiny, przede wszystkim w wymiarze gospodarczym, ale stopniowo również w zakresie bezpieczeństwa (Jeong-ho). W Dżibuti Pekin testuje nową strategię wykorzystywania potęgi gospodarczej do realizacji interesów w obszarze bezpieczeństwa. Inwestycje Chin w Dżibuti są bezprecedensowe w skali Afryki, a państwo to nie ma przecież surowców naturalnych, które Chiny mogłyby 
importować na większą skalę. Ma jednak strategiczną lokalizację, która może pomóc Pekinowi w zabezpieczeniu swoich interesów w regionie.

Mimo że Dżibuti znajduje się tysiące kilometrów od Chin i Stanów Zjednoczonych, to staje się ono ważnym punktem zapalnym w relacjach między tymi mocarstwami. Znamienne jest, że bazy tych państw są zlokalizowane są w odległości zaledwie $12 \mathrm{~km}$ od siebie, co stanowi ewenement wśród stałych baz wojskowych USA (Wang). Waszyngton obawia się, że budowa chińskiej bazy w Dżibuti i duży pakiet inwestycyjny Pekinu mogą doprowadzić do wypowiedzenia umowy o stacjonowaniu w tym państwie żołnierzy amerykańskich. Obserwatorzy spekulują, że w przyszłości baza amerykańska może zostać zastąpiona dużą, permanentnie rozwijaną bazą chińską. Taki rozwój wydarzeń byłby poważnym ciosem dla Pax Americana na świecie. Wynika to $\mathrm{z}$ faktu, że ta dominacja w dużej mierze opiera się na ochronie i do pewnego stopnia kontroli morskich szlaków komunikacyjnych. Jest to jednak mało prawdopodobne, przynajmniej w dającej się przewidzieć przyszłości. Wynikało to z faktu, że w maju 2014 r. prezydent Ismail Guelleh i prezydent Barack Obama (01.2009-01.2017) podpisali w Waszyngtonie umowę, która przedłuża o 20 lat dzierżawę terenu pod amerykańską bazę. Zgodnie z nią Pentagon rocznie płaci prawie $70 \mathrm{mln}$ USD za jego użytkowanie. Niemniej jednak, aby wzmocnić relacje na linii USA-Dżibuti, w maju 2015 r. Dżibuti odwiedził Sekretarz Stanu John Kerry (02.2013-01.2017), będąc pierwszym przedstawicielem USA tak wysokiej rangi składającym wizytę $\mathrm{w}$ tym państwie. Jednocześnie Waszyngton postanowił przeznaczyć 1,4 mld USD na modernizację Camp Lemmonier (Anadolu Agency). W okresie redukcji wydatków na zbrojenia ta decyzja pokazała strategiczną wartość tej instalacji dla Stanów Zjednoczonych.

Poza Stanami Zjednoczonymi o dominującą pozycję w basenie Morza Czerwonego rywalizują także mocarstwa i państwa z regionu. Ważne interesy ma tu przede wszystkim Arabia Saudyjska. Pod rządami króla Salmana ibn Abd al-Aziza Al-Sau'da (od 01.2015), a faktyczną władzą księcia koronnego i wicepremiera Muhammada ibn Salmana ibn Abd al-Aziza Al Su'uda (od 06.2017), Rijad próbuje zjednoczyć wszystkie państwa sunnickie z regionu i rugować wpływy irańskie. Ponadto zaangażowany jest w wojnę w Jemenie, zwalczanie Bractwa Muzułmańskiego i izolację Kataru. Ze względu na strategiczne położenie Dżibuti Arabia Saudyjska rozważa lokalizację swojej bazy w tym państwie. Ewentualna zgoda Dżibuti jest wysoce prawdopodobna ze względu na związki religijne, polityczne i gospodarcze partnerów. W działaniach w regionie Saudowie są wspierani przez Zjednoczone 
Emiraty Arabskie, które także rozwijają sieć swoich mniejszych baz w regionie, tj. w Puntlandzie, Somalilandzie i Erytrei.

Do rywalizacji o Morze Czerwone dołączył także Izrael. Przekazane przez Egipt Arabii Saudyjskiej dwie małe wyspy zamykające dostęp do Zatoki Akaba w rzeczywistości mają być kontrolowane przez Tel Awiw. Ponadto Izrael rozważa wykopanie Kanału Ben Guriona, który miałby połączyć Zatokę Akaby z Morzem Śródziemnym. Takie rozwiązanie zakończyłoby monopol w regionie Kanału Sueskiego. W kontekście prowadzonych rozważań szczególnie interesujące są plany budowy przez Izrael i Chiny linii kolejowej łączącej port Ejlat w Zatoce Akaba z wybrzeżem Morza Śródziemnego. Należy zaznaczyć, że obecnie Chiny łączą dobre, wciąż zacieśniane stosunki ze wszystkimi z tych państw, czego nie można powiedzieć o ich relacjach ze Stanami Zjednoczonymi.

Po wprowadzonej w czerwcu 2017 r. izolacji międzynarodowej spadło z kolei znaczenie Kataru, który wycofał swoje wojska ze spornej granicy między Dżibuti a Erytreą. Doprowadziło to do walk, których nie mogli powstrzymać ani Saudowie, ani Amerykanie. Niewielkie znaczenie w regionie ma także Rosja, a władze Dżibuti wykluczyły możliwość powstania na ich terytorium rosyjskiej bazy wojskowej (Repetowicz). Perspektywicznie coraz poważniejszym rywalem Chin w Afryce będą z kolei Indie, którym również zależy na kontroli wiodących do niej szlaków morskich. W ostatnich latach Chiny próbowały izolować hinduską flotę na Oceanie Indyjskim za pośrednictwem wspomnianego „Sznura Pereł” (Behrendt). Aby temu zapobiec, korzystanie z bazy w Dżibuti umożliwiła hinduskiej flocie Japonia. Należy także wspomnieć, że Chiny intensywnie zacieśniają wielowymiarową współpracę z najbliższym partnerem w Azji Południowej - Pakistanem.

Interesujące jest spojrzenie państw afrykańskich na wzmożoną aktywność ChRL w regionie. Zasadniczo państwa afrykańskie pozytywnie postrzegają działania pokojowe i antypirackie PLA. Mimo zastrzeżeń dotyczących traktowania miejscowej siły roboczej, również przychylnie odnoszą się do chińskich inwestycji. Debata nad długofalowym zwiększeniem obecności wojskowej Państwa Środka w regionie jest ograniczona i nie budzi poważniejszych kontrowersji. Sprzyja to polityce informacyjnej Pekinu, który nie chce, aby jego działalność była postrzegana jako przejaw strategicznej rywalizacji ze Stanami Zjednoczonymi i innymi mocarstwami oraz element wyścigu zbrojeń (Jeong-ho). Gospodarcze zaangażowanie się Chin w Afryce w XXI wieku ma istotny wpływ na zmianę oblicza tego kontynentu. Akcentowana przez Pekin zasada nieangażowania się $\mathrm{W}$ sprawy wewnętrzne 
państw afrykańskich stanowi jednak wyzwanie wobec konieczności ochrony interesów gospodarczych na kontynencie (Hess 152-153).

W Biatej Księdze Bezpieczeństwa z 2015 r. dla opisania nowej doktryny morskiej chiński rząd wprowadził określenie „obrona mórz przybrzeżnych, ochrona mórz otwartych". Drugi człon tego zwrotu odnosi się do odpowiedzialności PLAN za ochronę chińskich interesów za granicą. W dokumencie wskazano, że chińska flota wojenna stopniowo będzie przenosiła swoje skupienie z bliskich mórz na morza odległe. W tym celu ma rozwijać kompleksowe, wielofunkcyjne i skuteczne zdolności działań na różnych akwenach („China's Military Strategy”). Wzrastające interesy gospodarcze i handlowe Chin w regionie niosą za sobą potrzebę ich zabezpieczenia w oparciu o czynnik wojskowy. Realizacja inicjatywy OBOR między innymi w regionie Bliskiego Wschodu i Afryki Wschodniej stworzyła podstawy do zaspokojenia ambicji PLA wzmocnienia pozycji na morzach i oceanach. Ochrona szlaku morskiego przez PLAN potencjalnie zwiększy zainteresowanie przedsiębiorstw chińskich do inwestowania $w$ regionie.

Jak wynika z powyższego dokumentu, w Chinach porzucone zostało myślenie, że znaczenie lądu przeważa nad wagą mórz i oceanów. Nadaje on ogromne znaczenie zarządzaniu obszarami morskimi oraz ochronie praw i interesów ChRL na morzach. Strategia głosi konieczność rozwoju sił morskich odpowiednio do potrzeby ochrony odległych interesów w obszarze bezpieczeństwa i rozwoju. Potencjał morski znalazł się wśród czterech głównych obszarów rozwoju PLA, tj. obok sił nuklearnych, przestrzeni powietrznej i kosmicznej oraz cyberprzestrzeni („China’s Military Strategy”).

Baza w Dżibuti jest swego rodzaju „laboratorium doświadczalnym” dla PLA w zakresie wykorzystywania terytorium innego państwa do ochrony zamorskich interesów. Zanim Dżibuti zostało wybrane na lokalizację pierwszej zagranicznej bazy morskiej Chin, pod uwagę były brane również inne miejsca. Związany z PLA Chiński Instytut Badań Morskich (Chinese Naval Research Institute) rozpatrywał możliwość umiejscowienia bazy w mieście Sittwe w Mjanmie, Gwadar w Pakistanie, Hambantota na Sri Lance, Dar es Salaam w Tanzanii oraz na Seszelach. Miejsca te były brane pod uwagę ze względu na ich strategiczne położenie i znaczenie gospodarcze (Wang). Istnieje bardzo duże prawdopodobieństwo, że w celu zabezpieczenia swoich zamorskich interesów Chiny będą budowały kolejne bazy. Już na początku 2018 r. pojawiła się pogłoska, że Chiny przygotowują się do budowy drugiej bazy morskiej, tym razem w portowej miejscowości Jiwani w sąsiedztwie Gwadar w Pakistanie. Lokalizacja bazy w tym państwie jest prawdopodobna 
zważywszy na bardzo dobre stosunki między Pekinem a Islamabadem i kluczowe znaczenie tego miejsca dla chińsko-pakistańskiego korytarza gospodarczego (Chan).

Według China Security Report 2019, wydanego w lutym 2019 r. przez Japoński Państwowy Instytut Studiów Obronnych (Japan's National Institute for Defence Studies), „Chiny nie tylko dyskutują o reorganizacji porządku międzynarodowego, ale także stopniowo podejmują coraz bardziej zdecydowane kroki do jej faktycznej realizacji” (NIDS China Security Report 2019). W głównej mierze przyczynia się do tego inicjatywa OBOR i będące jej konsekwencją wzmacnianie obecności PLA na obszarach kluczowych dla jej przebiegu. Jednym z takich strategicznych miejsc jest baza wojskowa w Dżibuti. Eksperci zachodni, a szczególnie amerykańscy, w większości wskazują, że budowa bazy w Dżibuti to kolejny krok w globalnej dyslokacji wojsk PLA. Ma to być przejaw nasilenia strategicznej rywalizacji ze Stanami Zjednoczonymi poprzez przeniesienie jej również na poziom militarny (Repetowicz).

\section{ZAKOŃCZENIE}

W ostatnich latach ChRL przyjmuje coraz większą odpowiedzialność za międzynarodowe bezpieczeństwo i realizuje bardziej asertywną politykę zagraniczną. Pojawiły się tendencje sugerujące, że Pekin oczekuje uznania przez społeczność międzynarodową swojego statusu wielkiego mocarstwa. W okresie prezydentury Xi Jinpinga można zaobserwować trzy główne trendy. Po pierwsze, Chiny bardziej zdecydowanie angażują się w sprawy międzynarodowe, w tym aktywnie działają na forum międzynarodowych instytucji na rzecz utrzymania pokoju i bezpieczeństwa. Po drugie, zwiększają swoje międzynarodowe wpływy poprzez inicjatywy polityczne i gospodarcze na czele z OBOR i AIIB. Po trzecie, są bardziej stanowcze w kwestii sporów terytorialnych, głównie na Morzu Południowochińskim, i zwiększają obecność wojskową zarówno w sąsiedztwie, jak i na odległych akwenach (Lee).

Misje morskie, takie jak obrona wybrzeża, zapewnianie bezpieczeństwa na przyległych wodach czy nawet operacje antypirackie, były elementem chińskiej tradycji wojskowej przynajmniej od XIV wieku. Z drugiej jednak strony jak dotąd misje dalekomorskie nigdy nie były praktycznym rozwiązaniem dla chińskiej floty (Wilson 17). W zasadzie ograniczały się one do działań stricte cywilnych w zakresie handlu i inwestycji (Ross 59). Z per- 
spektywy teorii realizmu, a także dotychczasowych dziejów świata wynika, że rozwój gospodarczy przekłada się na wzmocnienie zdolności wojskowych. To z kolei budzi pragnienie dominacji w regionie, a często także zamorskej ekspansji (Liegl 2). Współcześnie Chiny próbują przejąć kontrolę nad przylegającymi do nich akwenami. Największe tarcia widać na Morzu Południowochińskim, na którym rywalizują one o wyspy Paracelskie i Spratly z Brunei, Filipinami, Malezją, Tajwanem i Wietnamem. Stawką w tym sporze jest kontrola kluczowego dla Chin akwenu z punktu widzenia bezpieczeństwa handlu morskiego, w tym dostaw surowców energetycznych (Liegl 237-238). Nasilające się terytorialne żądania ChRL, szczególnie na Morzu Południowochińskim, są postrzegane przez jej sąsiadów za dowód rozpoczęcia strategicznej ekspansji. Potwierdzeniem tego ma być także bardziej asertywna postawa w stosunku do dominujących na świecie Stanów Zjednoczonych (Yee i Storey 198). Podobne obawy wzbudza program szybkiej modernizacji chińskiej armii, w tym jej floty wojennej. Rozwój PLAN dotyczy zarówno okrętów nawodnych różnego typu, jak i łodzi podwodnych, w tym o napędzie atomowym. Kolejnym ważnym krokiem jest budowa grupy uderzeniowej lotniskowców. Mimo dynamicznego rozwoju PLAN nadal pozostaje jednak daleko w tyle za Marynarką Wojenną USA. Dynamiczny wzrost wydatków na zbrojenia ChRL w ostatnich latach stwarza jednak szansę, że ta różnica będzie stopniowo zmniejszana.

Budowa bazy w Dżibuti jest istotnym potwierdzeniem zwiększającego się zaangażowania militarnego ChRL na wodach okalających południową Azję i wschodnią Afrykę. W ten sposób Chiny chcą zabezpieczyć obszar, przez który przechodzić ma Morski Jedwabny Szlak. Dla Pekinu niezwykle ważną kwestią jest zapewnienie swobody żeglugi na handlowych trasach morskich. Zaangażowanie w zwalczanie piractwa morskiego w okolicach Somalii i Jemenu pokazuje, że PLA odgrywa w tym zakresie coraz większą rolę w środowisku międzynarodowym (MacDonald 184). Co ciekawe, wielu obserwatorów i badaczy uznało bezprecedensowe uczestnictwo chińskiej floty w misji antypirackiej w Zatoce Adeńskiej nie tylko za przejaw wzrostu odpowiedzialności ChRL za międzynarodowe bezpieczeństwo, ale także jako ważny krok ku zwiększeniu jej obecności wojskowej na Bliskim Wschodzie i w Afryce (Shichor 119). Wrażenie to potęguje wzrastająca liczba żołnierzy delegowanych do misji pokojowych.

Obecnie nie ma pewności co do zakresu ambicji wojskowych Chin w regionie Afryki. Jak dotychczas baza Obock ma głównie charakter ośrodka wspomagającego okręty chińskiej floty cywilnej i wojskowej. Jeśli w bazie 
w Dżibuti rozwijane będą zdolności w zakresie dowodzenia i kontroli (Command and Control - C2) oraz morskiej obserwacji (Maritime Surveillance) to wskazywałoby to kierunek stworzenia stałej siły morskiej na Oceanie Indyjskim i akwenach Bliskiego Wschodu. Mogłoby to stanowić próbę równoważenia dowództwa amerykańskiej Piątej Floty (Fifth Fleet) w Bahrajnie (Henry 4). W rzeczywistości nie należy się jednak spodziewać, że baza w Dżibuti przejmie odpowiedzialność za dowodzenie wojskowymi operacjami morskimi („Djibouti - China Naval Base”) ${ }^{1}$. Bardziej prawdopodobne jest, że taką funkcję będzie pełniła inna baza morska zbudowana w przyszłości przez ChRL.

\section{BIBLIOGRAFIA}

Anadolu Agency. „John Kerry visits Djibouti as the first US Secretary of State to visit the country”. Daily Sabah, 6 May 2015, www.dailysabah.com/africa/2015/05/06/john-kerry-visits-djiboutias-the-first-us-secretary-of-state-to-visit-the-country. Dostęp 18.07.2019.

Becker, Jeffrey, i Erica Downs. „China’s Djibouti military base the first of many”. East Asia Forum. 27 June 2018, www.eastasiaforum.org/2018/06/27/chinas-djibouti-military-base-the-first-ofmany/. Dostęp 18.07.2019.

Behrendt, Paweł. „Chiny starają się umocnić swoją pozycję w regionie Oceanu Indyjskiego”. Centrum Studiów Polska-Azja, 24 lutego 2015, www.polska-azja.pl/p-behrendt-chiny-staraja-sieumocnic-swoja-pozycje-w-regionie-oceanu-indyjskiego/. Dostęp 18.07.2019.

Chan, Minnie. „First Djibouti ... now Pakistan port earmarked for a Chinese overseas naval base, sources say". South China Morning Post. 5 January 2018, www.scmp.com/news/china/diplomacydefence/article/2127040/first-djibouti-now-pakistan-port-earmarked-chinese. Dostęp 18.07.2019.

Cheng, Amy. „Will Djibouti Become Latest Country to Fall Into China's Debt Trap?”. Foreign Policy, 31 July 2018, foreignpolicy.com/2018/07/31/will-djibouti-become-latest-country-to-fallinto-chinas-debt-trap/. Dostęp 18.07.2019.

„China's Military Strategy”. Beijing. The State Council, May 2015, english.gov.cn/archive/ white_paper/2015/05/27/content_281475115610833.htm. Dostęp 12.07.2019.

Dend, Young. „The Elusive Progress: Sino-American Military Relations”. Sino-American Relations. Challenges Ahead, red. Yufan Hao, Routledge, 2016, ss. 95-111.

„Djibouti - China Naval Base”. Global Security, www.globalsecurity.org/military/world/djibouti/ forrel-prc-base.htm. Dostęp 18.07.2019.

Downs, Erica, Jeffrey Becker i Patrick deGategno. China's Military Support Facility in Djibouti: The Economic and Security Dimensions of China's First Overseas Base. CNA, 2017.

Hayoun, Massoud. „China's Approach to the Middle East Looks Familiar”. The Diplomat, 29 November 2016, thediplomat.com/2016/11/chinas-approach-to-the-middle-east-looks-familiar/. Dostęp 18.07.2019.

\footnotetext{
${ }^{1}$ „Djibouti - China”.
} 
Headley, Tyler. „China’s Djibouti Base: A One Year Update”. The Diplomat, 4 December 2018, thediplomat.com/2018/12/chinas-djibouti-base-a-one-year-update/. Dostęp 18.07.2019.

Henry, Jérôme. China's Military Deployments in the Gulf of Aden: Anti-Piracy and Beyond. Institut français des relations internationales, 2016.

Hess, Steve. Richard Aidoo, Charting the Roots of Anti- Chinese Populism in Africa. Springer, 2015.

Jeong-ho, Lee. „How the tiny African nation of Djibouti became the linchpin in China's belt and road plan”. South China Morning Post, 28 April 2019, www.scmp.com/news/china/diplomacy/ article/3007924/how-tiny-african-nation-djibouti-became-linchpin-chinas-belt. Dostęp 18.07.2019.

Lanteigne, Marc. Chinese Foreign Policy. An introduction. Third edition. Routledge, 2016.

Lee, Raymond. „Implications of the War in Yemen on China”. Aljazeera, 10 June 2015, studies.aljazeera.net/en/reports/2015/06/2015610104657143413.html. Dostęp 18.07.2019.

Li, Jingkun, Chen Zhao, Lei Zhang, Hui Cao i Haiyang Zhang. „China-EU Political Relations”. China-EU Relations. Reassessing the China-EU Comprehensive Strategic Partnership, red. Hong Zhou, Springer, 2017, ss. 35-68.

Li, Mingjiang, Kalyan Kemburi i Andzhang Hongzhou. „Growth of China’s power: capabilities, perceptions, and Practice”. China's Power and Asian Security, red. Mingjiang Li i Kalyan M. Kemburi, Routledge, 2015, ss. 3-24.

Liegl, Markus B. China's Use of Military Force in Foreign Affairs. The Dragon Strikes. Routledge, 2017.

Lubell, Aviv. „War in Yemen compromises China's naval strategy”. Global Risk Insights, 15 April 2015, globalriskinsights.com/2015/04/war-in-yemen-compromises-chinas-naval-strategy/. Dostęp 18.07.2019.

MacDonald, Adam. „Access, Assurance and Acceptance”. Facing China as a New Global Superpower. Domestic and International Dynamics from a Multidisciplinary Angle, red. Huhua Cao i Jeremy Paltiel, Springer, 2016, ss. 171-196.

Maslow, Sebastian. „China and Japan: partner, rival, and enemy?”. China's International Roles Challenging or supporting international order?, red. Sebastian Harnisch, Sebastian Bersick i Jörn-Carsten Gottwald, Routledge, 2016, ss. 188-206.

NIDS China Security Report 2019: China's Strategy for Reshaping the Asian Order and Its Ramifications". Tokyo. National Institute for Defense Studies. February 2019, www.nids. mod. go.jp/publication/chinareport/pdf/china_report_EN_web_2019_A01.pdf, 2. Dostęp 18.07.2019.

Repetowicz, Witold. „Chiny w Dżibuti: nowe rozdanie w geopolitycznej rozgrywce”. Defence24. 16 lipca 2017, www.defence24.pl/chiny-w-dzibuti-nowe-rozdanie-w-geopolitycznej-rozgrywce. Dostęp 18.07.2019.

„Resolution 1816 (2008). Adopted by the Security Council at its 5902nd meeting on 2 June 2008”. New York, UNDOCS.ORG, undocs.org/S/RES/1816(2008). Dostęp 12.07.2019.

Ross, Robert S. Chinese Security Policy. Structure, power and politics. Routledge, 2009.

Shichor, Yitzhak. „Maximising output while minimising input: change and continuity in China's Middle East policy". Chinese Foreign Policy Under Xi, red. Hoo T. Boon, Routledge, 2017, ss. 109-129.

Szumski, Krzysztof. „Nowa polityka zagraniczna prezydenta Chin Xi Jinpinga”. SWPS, www.swps.pl/ nauka-i-badania/materialyccaw/2432-nowa-polityka-zagraniczna-prezydent-chin-xi-jinpinga.

Dostęp 18.07.2019. 
Wang, Monica. „China's Strategy in Djibouti: Mixing Commercial and Military Interests”. Council on Foreign Relations, 13 April 2018, www.cfr.org/blog/chinas-strategy-djibouti-mixingcommercial-and-military-interests. Dostęp 18.07.2019.

Wilson, Andrew R. „Myth-busting: challenging the conventional wisdom on Chinese strategic culture". China's Strategic Priorities, red. Jonathan H. Ping i Brett McCormick, Routledge, 2016, ss. 8-23.

Yee, Herbert, i Ian Storey. „Introduction”. The China Threat: Perceptions, Myths And Reality, red. Herbert Yee i Ian Storey, RoutledgeCurzon, 2002, ss. 1-20.

Yuan, Jing Dong. „The coming US-China military showdown in Asia: why it could happen, and how it can be prevented". New Dynamics in US-China Relations. Contending for the AsiaPacific, red. Li Mingjiang i Kalyan M. Kemburi, Routledge, 2015, ss. 168-186.

\section{UWARUNKOWANIA BUDOWY I ROZWOJU \\ BAZY MORSKIEJ CHIŃSKIEJ REPUBLIKI LUDOWEJ W DŻIBUTI}

Streszczenie

Przedmiotem artykułu są uwarunkowania budowy i rozwoju bazy morskiej Chińskiej Republiki Ludowej w Dżibuti. Składa się on ze wstępu, trzech części i zakończenia. We wstępie omówione zostały założenia metodyczne artykułu. W pierwszej części przedstawiono powody lokalizacji pierwszej zagranicznej bazy morskiej Chin w Dżibuti. Druga część została poświęcona kwestiom budowy i rozwoju bazy. W trzeciej części przeanalizowano konsekwencje umiejscowienia chińskiej bazy w Dżibuti dla strategicznej rywalizacji między panstwami. Badania uwzględniają zarówno perspektywę lokalną, regionalną, jak i globalną. W zakończeniu zamieszczono najważniejsze wnioski i podsumowania oraz perspektywy rozwoju bazy w Dżibuti i dalszych działań ChRL w zakresie morskiej ekspansji.

Słowa kluczowe: Chińska Republika Ludowa; Dżibuti; baza morska; marynarka wojenna; inwestycje gospodarcze. 